This is the version of the article accepted for publication in International Journal of Middle East Studies published by Cambridge University Press: https://www.cambridge.org/core/journals/international-journalof-middle-east-studies

Accepted version downloaded from SOAS Research Online: http://eprints.soas.ac.uk/30419

\title{
Shiny Things and Sovereign Legalities: Expropriation of Dynastic Property in the Late Ottoman Empire and Early Turkish Republic
}

In December 1909, a recently manumitted concubine named Layık Seza petitioned the office of the Grand Vizier to claim a piano she had left behind at Yildız Palace, where she was expelled following Abdülhamid II's deposal earlier that year. ${ }^{1}$ Like many others before her, Layik Seza was brought to the imperial palace as a young girl, where she built her world around things she earned for the "good deeds" she had done for the benefit of the Ottoman state. On the one hand, she well knew that nothing she had was hers to own. The property of the enslaved members of the Ottoman court was ordinarily confiscated, not only upon their death but in the event of a sultan's deposal as well. ${ }^{2}$ On the other hand, however, she also knew that she could claim the piano only as her personal property. "For they gave back our personal items," she explained with studied naivety in her petition, "but they [must] have forgotten to return my mahogany colored piano." ${ }^{3}$ She intuitively grasped that, as the Ottoman Empire moved from one mode of rule to another, from absolute to constitutional monarchy, layers of meanings that the piano previously held in relation to sovereign power collapsed into one: it became the personal and private property of — and, had to be claimed as such by — a person who herself had been the property of the Ottoman state until recently.

Lay1k Seza's personal campaign to recover her piano exemplified many features of the rupture and subsequent ambiguity of ownership of dynastic property caused by the 1908 constitutional revolution in the Ottoman Empire. The revolution brought new 
limitations and significance to the physical and public presence of the Ottoman state embodied in the buildings and "things" that had hitherto been the symbols of imperial dominion and prerogative. ${ }^{4}$ To be sure, both the material presence of the Ottoman state and the complicated ownership systems of the sovereign's property had already been in flux in the previous centuries. ${ }^{5}$ Concomitant with the global preoccupation with the setting of "universal standards for the holding of property" on the one hand and the parallel development of the liberal project of res publica on the other, the relationship of the modernizing Ottoman state to the material space continued to transform significantly throughout the nineteenth century. ${ }^{6}$

This transformation was further intensified, with a touch of ambivalence, during the reign of Abdülhamid II, whose welfare policies helped to expand the public domain through increasing number of public works and institutions. On the flipside, however, Abdülhamid II extensively exploited this expanding domain through a set of invented traditions that aimed to restore the sacredness of the sultan's person, ${ }^{7}$ effecting a ceremonial and material presence of the state reminiscent of earlier times. ${ }^{8}$ It was in this context that the "sanctum" of his rule, Y1ldiz Palace, assumed a particular significance. 9 It was also in this context that, in the aftermath of his deposal in 1909, Y1ldiz Palace was singled out as a "monument of despotism" by the constitutional regime, whose subsequent desire to legitimately expropriate it brought about the first immediate challenges of determining the jurisdictional limits of public ownership of property and coming to terms with the question of what it meant for the "the people" to own "things." 10 
Focusing roughly on the two decades that spanned from Abdülhamid II's deposal in 1909 to the few years that followed the abolition of Caliphate in 1924, this article probes the legislative process of the expropriation of dynastic property by the late Ottoman and early Turkish Republican states at a time when their milieu of jurisdiction shifted significantly. It takes lengthy—and often utterly confused—parliamentary debates as entry points for exploring the nature of this expropriation process as a means to redefine sovereignty and the sovereign's relationship with property on the one hand and to discursively create "political legitimacy and popular consent," on the other. ${ }^{11}$ To be sure, this was a gradual process that hardly extended to other imperial buildings and things than Yildı Palace at the time. Nonetheless, as this article aims to show, the initial debates and the subsequent expropriation of Yildız Palace helped, heuristically, shaping a new understanding of public ownership of property that was put into use in other instances in the years to come, most notably during and after the First World War and the Armenian genocide, before establishing itself as the foundation of a new property regime with the republican appropriation and reuse two decades later.

Historians of the late Ottoman Empire studied the state (trans)formation in this period extensively yet often treated, as Nadir Özbek aptly criticized, the Ottoman and the Republican states as "supreme and ever-present political actor[s]," which rarely appeared in doubt as to their limits. ${ }^{12}$ Recently, highly innovative work has been undertaken by the scholars of Greek and Bulgarian expulsions, the Armenian genocide, and the concomitant property confiscations and expropriations in the post-genocide Ottoman Empire. ${ }^{13}$ These studies have effectively demonstrated that it was this intensive confiscation and destruction process that helped the Ottoman and early Republican governments to 
consolidate their power, not only economically but also ideologically. ${ }^{14}$ It was also during this process that the legal and extralegal foundations of this new understanding of public ownership, and its intrinsic ties to national wealth and economy, were established. However, they too inevitably treat the Ottoman and Republican states as "concrete political bod[ies] and unified public actor[s]" that deployed their sovereign will to constitute exceptions and cause the destruction of those they set aside as the "accursed people." 15

While the expropriation of dynastic and non-Muslim property paralleled each other and were intimately linked, ${ }^{16}$ the two processes also display some useful differences. For one, although there was ample ambiguity inherent in drafting and implementing laws on abandoned Greek or Armenian property, ${ }^{17}$ the overt hesitation and confusion in regards to the dynastic property, which loomed large in all parliamentary sessions, surpassed the former. This stemmed from distinct problems that were directly linked to the nature of dynastic property, which had to do with the classic, convoluted relationship of the person of the sovereign to the legal realm, particularly in regards to property ownership. Islamic jurisprudence and the accompanying administrative regulations had traditionally distinguished the private treasury of the sovereign (bayt māl al-khhāṣsa) from the fiscus or public treasury (bayt māl al-musliminn), but the line between the two was by no means clear-cut. ${ }^{18}$ For the constitutional government, legal categorization of Abdülhamid II's property after his deposal proved to be challenging, to say the least. Moreover, it was anything but a simple task to determine the limits of the person of the deposed sovereign, and sever him from the remainder of the Ottoman dynasty. 
Secondly, both the Constitutional and the Republican governments used the imperial buildings and the "shiny things" they contained as beacons of the imagined majesty of the Ottoman Empire, which uncomfortably sat side by side with what came to be increasingly perceived as its undesirable past; first, against the Hamidian past and second, the Ottoman past as a whole. In what follows, this article traces the ways in which the Constitutional and Republican governments tried to tackle or circumvent these problems, with the overarching goal of understanding how the accompanying discordances, misconceptions, and ambiguities shaped the meanings of and the relationship between the state, the public domain, and property ownership in the late Ottoman Empire and the early Turkish Republic.

\section{The Problem of Dynastic Property in the Constitutional Order}

Often portrayed as a watershed moment in the late Ottoman historiography, the 1908 constitutional revolution was, in effect, no more than a "triumphant" reinstatement of an earlier, disrupted constitutional regime. ${ }^{19}$ Although carried out largely by military personnel, the revolution did not necessarily have a military character at the beginning. Nor did it bring an end to Abdülhamid II's rule, even though the revolutionaries defined their oppositional politics often explicitly in reference to the heavy-handed rule of the former. What constituted more of a rupture than the 1908 revolution was the counterrevolution that broke out in mid-April the following year. Ambiguously viewed by the historians at once as Abdülhamid's attempt to regain power, the Liberal opposition's provocation, and the Committee of Union and Progress's (CUP) plot to take hold of the 
central power militarily, ${ }^{20}$ the government's crushing reaction to the counter-revolution achieved what the revolution did or could not earlier. During the nine days that it lasted, the "revolutionary fervor" that was nonexistent in the first phase of the revolution helped the CUP government do away with the governmental "impotence," for which it had heretofore been firmly criticized. ${ }^{21}$ As a result, the violent suppression of the counterrevolution by the government-organized Action Army not only effectively brought an end to the absolutist rule in the Ottoman Empire but also conspicuously militarized the political sphere. ${ }^{22}$

It was also this "fervent" revolutionary moment that marked the beginning of the dissolution of the imperial palace, in this case primarily Y1ldız Palace, as a political institution. ${ }^{23}$ Accordingly, the first parliamentary debates on the ownership of imperial property and its public and private character took place immediately after the disturbances were brought to an end. In the ensuing months, the parliamentarians debated legitimate ways of handling Yıldız Palace and things that it contained, with the aim of sketching a legal framework for the undertaking and determining the liabilities of the institutions that would carry out the process, including the liabilities and responsibilities of the legislature itself.

The first official proposal on the issue was opened to deliberation shortly after the parliament reconvened on 1 May 1909, which suggested that a parliamentary commission be drawn up and accompany the inspectors employed by the Istanbul Municipality (Şehremaneti), the institution authorized to carry out the inspection and assessment of the Yıldız Palace buildings and its contents. ${ }^{24}$ While a general procedural ambiguity predominated in the sessions thereupon, several deputies readily agreed on their objection 
to the Istanbul Municipality's involvement in the matter, partly because the legitimacy and the necessity of the institution had begun to be contested also around this time. ${ }^{25}$ For one, the Sinop deputy Hasan Fehmi Efendi maintained that overseeing this process was the responsibility of the central government, particularly that of the Ministry of Finance and should not be left to the Municipality at all. ${ }^{26}$ Siroz (Sérres in today's Greece) deputy Hiristo Dalçef Efendi also objected to the Istanbul Municipality's primary involvement in the process, contending that the wealth housed in and extracted from Y1ld1z Palace did not belong to the imperial capital alone, but to the entire "nation." 27 Other deputies were concerned more specifically about the legal dimensions of the process. For Antalya deputy Ebüzziya Tevfik Bey, who was known to be less than an ardent supporter of the constitutional order, the Ottoman law commended that all this wealth to be transferred to the new sultan, and no government institution had the right to inspect or confiscate any of it. ${ }^{28}$ For Nafi Pasha, a deputy from Aleppo on the other hand, treasures of Y1ldiz should be considered beytü'l mal, the inspection of which was primarily a matter of the sharín law, to be supervised by the office of the şeyhülislām (shaykh al-Islām, chief religious official in the Ottoman Empire, one that oversaw the Islamic shar $\bar{\imath}$ 'a legal order, as well), ${ }^{29}$ a claim that was taken up by another Aleppan, Ali Cenani, the following day, who defined Abdülhamid II's wealth and property as "extorted" from the people during the "era of despotism," and could and should be taken back by "the people" precisely because it was beytü'l mal..$^{30}$

In the following months, deputies continued to bring in and negotiate their understanding of what public property meant and how they, as the presumed representatives of the people, were to handle it. All in all, neither the legislature nor the 
executive branch of the government had a clear idea on the legal procedure as to how Yıldız Palace and the property found in it would be handled, and often more than one legal and administrative body was deemed entitled to supervise this process. In the meantime, however, the commander of both the Third Army Corps and the Action Army Mahmud Şevket Pasha sent telegrams to the parliament to report that all cash and a portion of the valuable items found at Yildız Palace had already been seized and removed by the army and secured at their headquarters. ${ }^{31}$ In these telegrams, Mahmud Şevket Pasha stated, with utmost authority, that the parliament should not intervene in the process, as divan-ı harbi örfí (court martial during the declared state of emergency) regarded this a necessary measure, although their participation by sending "two or three individuals" to observe it was deemed appropriate. ${ }^{32}$ In that, while the government grappled with the jurisdictional limits and definitions of deposal and dissolution, revolutionary fervor had already placed its mark on the process and made it essentially militaristic in nature.

The more critical questions came when the actual sorting and assessment process began. What exactly was subject to the proposed and subsequently carried out inspection and confiscation? Did it apply only to cash and valuable items, such as jewelry, or did it also include title deeds, equity shares and bonds that the deposed sultan kept in the banks? Was it only sultan Abdülhamid II's personal wealth and if so, where did his 'person' really end? As had been recurrently voiced in the subsequent debates, no justification was necessary for the proposed confiscation of Abdülhamid II's personal property, as all of it was considered to have been acquired through illegitimate means. ${ }^{33}$ The case for his extended family, on the other hand, which technically included his 
brother, the reigning sultan Mehmed V Reşad, was different and more difficult to determine. Despite the recent constitutional amendments that brought limitations to the sultan's executive and legislative powers, ${ }^{34}$ Mehmed V Reşad was still the legitimate ruler of the empire and the owner of the dynastic property. Thus, careful definition and excision of Abdülhamid II's personal wealth from the remainder of the dynastic wealth was a difficult but a necessary task.

The initial measures, to that effect, were no more than a set of spontaneous decisions to confiscate all movable and real property that belonged to Abdülhamid II and his immediate family. Accordingly, in a proposal, which was opened to deliberation on the 4 May 1909 sitting, the Commission on Budgetary Balance (Muvazene Encümeni) suggested that all wealth owned by Abdülhamid II and his family, including cash, stocks and bonds held in foreign institutions, be seized. ${ }^{35}$ Fearing that his family members would transfer money and valuable items (which at this time were already referred to as "the people's" property (milletin mall)) outside the country, the commission also deemed it necessary to obtain restrictive orders for all corresponding bank accounts and bring strict control on the movement of all family members, ${ }^{36}$ a fear that proved well-founded when şehzade Burhaneddin Efendi, one of Abdülhamid II's sons, was captured while trying to flee Istanbul two weeks later, carrying with him 20,000 lira worth of cash and checks. ${ }^{37}$ The government consequently arrived at the decision that Abdülhamid II's personal property alone was to be confiscated and an official note from the office of the Grand Vizier established that everything he purchased, appropriated, and extorted both before and after he was enthroned in 1876 was subject to this confiscation. ${ }^{38}$ In other words, the constitutional government determined not only where the person of the 
deposed sovereign ended but also how far back in time it extended. However, they still needed to locate this wealth in place, which posed another challenge in an already exceedingly globalized financial world.

Were this solely a domestic issue, it would be an easy matter, Ahmed Bey, the acting president of the Commission on Budgetary Balance maintained. But the dethroned sultan spread his wealth virtually to all over the globe. ${ }^{39}$ Reclaiming the "things" held in those accounts in the name of the people (millet) was not a simple, if at all a possible task. As the deputies collectively noted, the foreign banks would be very unlikely to return the money, bonds and stocks they held on a simple request. The matter had to be reviewed in reference to the law (kanun dairesinde) and an official consultation needed to be communicated to the executive branch. But what did the law prescribe on this procedure exactly? The question was raised rather dispiritedly by the Istanbul deputy Hallacyan Efendi, to which the Üsküp (Skopje, in today's Macedonia) deputy bluntly responded: "Nothing." ${ }^{40}$ But surely the international law, implied to have the upper hand in matters related to "haute finance," must have dealt with similar cases before, Hallacyan Efendi maintained, which they also could refer to. In the year that followed, the despairing and occasionally dumbfounded government embarked upon the process of collecting back Abdülhamid II's money, bonds or stocks. ${ }^{41}$ Some of these collection processes were rather straightforward and were brought to a conclusion within a few months, ${ }^{42}$ while others, such as the ones with the Crédit Lyonnais or Reichsbank, the processes were remarkably complicated and took much longer time to resolve. ${ }^{43}$ All in all, regardless of their straightforwardness or complexity, these cases helped the 
constitutional government to come to terms with the broader, international limits of their (re)envisioned sovereignty.

Together with the valuable items found at Yildı Palace and other wealth confiscated through domestic channels, all was transferred to the Ministry of Finance, though not without another round of confused debates among the parliamentarians, that brings us back to the initial question, posed above in the introduction, with which this article concerns itself. What were the limits of the Ottoman state's ownership of these newly acquired funds? Or, to repeat the earlier question and put in more familiar terms, what did it mean for "the people" to own "things"?

What the government could and could not do with the confiscated money was first discussed shortly after the deposal of Abdülhamid II, over a formal inquiry by the Commission for Hejaz Railway (Hicaz Demiryolu Encümeni). According to the note sent by the Commission's president Abdülkadir Hâşimî, the deposed sultan had previously conceded 50,000 liras for the construction and maintenance of the railway, although the money was never received by the Commission. ${ }^{44}$ Continuing with the railway construction without any disruption was of utmost public importance, Abdülkadir Hâşimî contended, but also reliant on the availability of funds. It was thus that the Commission queried whether this amount could be set aside from the cash and valuables found at Yildiz Palace and at once deposited for the use of the Railway administration. ${ }^{45}$ This inquiry sparked a debate among the parliamentarians, some of whom were not even sure whether the amount in question was to be considered a gift or a debt. In either case, the main point of disagreement had to do with the nature and the definition of people's property (milletin mall). As the Sinop deputy Hasan Fehmi Efendi confirmed, the 
political, economic and religious importance and urgency of the Hejaz Railway could not be disputed, but the money found at Yıldız Palace belonged to the people (millet), who now seized and claimed it and could use it only in ways it pleased (keyfema yeşa') ${ }^{46}$

In addition to such large-scale projects, there were appeals for smaller and less valuable - though, no less important or urgent—resources particularly for the reusable items found at Yıldız Palace's residential quarters. One such request was for the transfer of Yıldız Palace's bedframes and copperware to the soon to be opened hospital in Cerrahpaşa ${ }^{47}$ Informed about these items, stacked up and idly waiting at the palace, the Directorate General for Health and Public Assistance (Müessesât-ı Hayriye-i Sthhiye Riyaseti) requested them for the hospital's use from the Municipal Government, who, in its turn asked the Ministry of Interior for their transfer. Similar to the large public projects, these requests also brought forth debates around the problem of "the people's" ownership of "things" and called for a legal definition and procedure, as well as a justification for the things' appropriation for public use. The items that were included in the Directorate General's list comprised no more than a few iron bedframes, copper pots and pans and straw matrasses, which held close to no value. Moreover, as the deputy mayor Tevfik Bey stated in support, they were left there unused, "to rust and decay whereas they could be of utmost use, serving the sick people of the city instead." ${ }^{\prime 48}$ The Municipal Government was short of funds, the deputy mayor further explained, and the hospital had urgency, thus despite having no value these items would ease the financial burden of the former. ${ }^{49}$ Even with such reasoning, however, the Ministry of Interior found this request unacceptable, until the Grand Vizier Hakk1 Pasha's involvement and the new sultan's approval of their transfer. ${ }^{50}$ 
The valuable items found at Yildı Palace, particularly jewelry, were consequently priced in accordance with expert assessments and reluctantly auctioned, bringing the state treasury a decent sum in the end. ${ }^{51}$ Less valuable items, which had potential public use, continued to slowly and cautiously flow towards the public institutions, both old and new. One such case was debated at the parliament within the larger context of budgetary planning, when the deputies voted in favor of transferring various tools and instruments in Y1ldiz Palace's observatory to a newly established meteorological station. ${ }^{52}$ Many other items were given away to a range of government institutions, most notably the Ministry of Education, to be utilized in schools ${ }^{53}$ The palace automobiles were requested by the Ministry of War. ${ }^{54}$

Once Abdülhamid's things were duly transposed, the focus of the debates shifted towards the built environment of Y1ld1z Palace itself, confiscation of which was more conspicuous than auctioning jewelry or disposing cash and had to be conceived publicly, with due precision and utmost legitimacy. From early on after Abdülhamid's deposal, there were suggestions to turn Y1ldiz Palace into a museum that would represent the struggle of "the people" against its "infamous resident." There were also other suggestions based on the immediate needs of "the people," and by extension, for the public good in general. Sinop deputy Hasan Fehmi Efendi, for one, suggested that the palace be given to the least funded of all Ottoman institutions; namely, the state almshouse (Darülaceze). ${ }^{55}$

In effect, the discourse on the needs and necessities of the "people" defined the contours of the ways in which Y1ldz Palace was put into use in the subsequent months. The palace gardens and part of the buildings were opened to public visits shortly after 
Abdülhamid II's deposal, allowing both Ottoman and foreign visitors to take guided or unguided tours. ${ }^{56}$ While the newspapers boasted a commercial return of 100 liras daily, the Yıldı Commission's efforts focused on the palace's public uses, determining along the way, what public use or benefit came to mean in general. ${ }^{57}$ For one, the Y1ldiz Commission used the palace grounds to organize social gatherings with appearances by the members of the Ottoman dynasty, with the purpose of raising money for the victims of anti-Armenian pogroms that had taken place in Adana several weeks earlier. ${ }^{58}$

There were other instances, however, in which the use of the palace buildings were more ideologically charged. Such was the case when the Committee of Union and Progress decided to hold a banquet at Yıldız Palace for the occasion of the first year anniversary of the revolution. ${ }^{59}$ In that, the handling of the palace grounds was not wholly untouched by the ideological effects of the regime change, but even so it was presented more as an act of retribution that aimed at "doing justice" on behalf of the people. Full ideologization of the expropriation process would take years of legislative work that regulated total mobilization, genocide, confiscation, destruction and appropriation, at the end of which the Turkish Republic emerged as the lawful owner of the whole of dynastic things.

\section{Wartime Appropriation and Republican Reuse}

As the dissolution of Yildız Palace was still underway in early 1910, a lowranking gendarmerie officer, who had been on duty in the makeshift station there, 
reportedly removed furniture from the palace with the purpose of furnishing a nearby gendarme station. ${ }^{60}$ Related correspondences between the Ministry of the Interior, the office of the Grand Vizier, and the Municipal Government all stated the unlawfulness of the items' transfer, which the officer carried out despite the fact that he was repeatedly advised against it. ${ }^{61}$ While the War Ministry's response is missing from the file, the continued correspondences indicate that those items were never returned to the palace premises. Unlike the Directorate General's request for the Cerrahpaşa Hospital, the Gendarmerie division did not have to make a case for itself, nor do they seem to have obtained the sultan's permission for the items' transfer. As indicated by Mahmud Şevket Pasha's commanding voice when he gave the ultimatum to the parliament a year earlier or the easiness with which the War Ministry claimed and obtained the palace automobiles a few months earlier, the army had the upper hand in the expropriation process. ${ }^{62}$ While the Ottoman Parliament often appeared to be in full support of it, particularly in the immediate aftermath of the 1909 counter-revolution, the actions of the military personnel did not always go unnoticed or uncontested. On the contrary, deputies openly voiced their criticism of the anomalous position held by the military in general and by Mahmud Şevket Pasha in particular. ${ }^{63}$

This situation changed drastically with the onset of the Balkan Wars that marked the beginning of what would be the final decade of the Ottoman Empire. Throughout this period of consecutive wars, total mobilization, and harsh suppression of all political opposition, the Ottoman state claimed its citizens' lives and property in its entirety, leaving only few facets of the Ottoman society untouched. ${ }^{64}$ To be sure, the Ottoman state had claimed the property of its subjects and citizens before the Balkan Wars as well. 
For one, it had customarily confiscated land and moveable property through the governmental practice of müsadere all throughout its existence. Yet, this practice targeted, at least in theory, the office and/or local power holders ${ }^{65}$ and rarely, if at all, translated into a wholesale dispossession. ${ }^{66}$ For instance, in the case of the abolition of the Janissary corps and the associated Bektashi sufi order, extensive confiscations were still limited to regimental property or that of the individuals prosecuted during or following the abolition. ${ }^{67}$

What is more important and relevant, perhaps, is that a number of legal "inventions," such as those related to the newly emerging welfare policies in the nineteenth century transformed the existing sharī'a provisions, gave an unprecedented license to the Ottoman state to intervene directly in the matters of personal and family property and act in the interest of the Ottoman poor and needy. ${ }^{68}$ In 1873 , for instance, the Ottoman state reportedly expropriated numerous houses and plots that belonged to a private waqf in Edirne, in support of the newly built state orphanage there. ${ }^{69}$ A good portion of these policies and concomitant legal changes were effected also by large-scale population displacements that began in the mid-nineteenth century, ${ }^{70}$ during which such categories as abandoned property in particular began to assume new meanings, ones that could be fairly different from classical provisions on the subject. ${ }^{71}$ In that, not only the standards for the holding of property, but also the very definition of sovereignty and its relationship to both "the people" and "things" transformed in the second half of the nineteenth and early decades of the twentieth centuries.

This transformation intensified in the final decade of the empire and, beginning with the implementation of the war taxes (tekalif-i harbiye) during the Balkan Wars, 
culminated in a series of laws that ordered the systematic confiscation of property for military purposes. ${ }^{72}$ More decisive than the military requisitioning in this context, however, was the coinciding process of large-scale dispossession of Bulgarians, Greeks, and later on Armenians during and after the World War I and the reformulated notion of abandoned property (emval-i metruke), which emerged as its immediate outcome. As already mentioned, the legal category of abandoned property, which had historically been one of the subsidiary income sources that constituted beytü'l mal, ${ }^{73}$ was not a new invention. Already in flux earlier in the nineteenth century, however, it assumed a whole new significance with the onset of the Bulgarian and Greek expulsion in 1913 and particularly throughout the Armenian genocide, and became the central concern of the subsequent governments, both economically and ideologically, in their efforts to redefine who the sovereign was and how it related to the holding of property. ${ }^{74}$

As with the constitutional government's take over of the dynastic property a few years earlier, the central question in relation to the appropriation of "abandoned" nonMuslim property was that of legitimacy. ${ }^{75}$ While this process began during the Balkan Wars, the first law that regulated the confiscation of abandoned property, albeit a temporary one, did not come until September $1915 .{ }^{76}$ Generically entitled "the law about the abandoned properties, debts and credits of the population who were transferred to other locales," the decree stipulated that all real property be registered by the treasury of the Ministry of Finance, whereas all moveable property had to be gathered and assessed by a commission, to be duly auctioned and sold. ${ }^{77}$ The corresponding money would then be given to the local subdivisions of the Treasury, to be eventually returned to the actual owner of the items, a stipulation that was fully overridden by laws enacted at different 
times, that gradually transferred all of the property to the state budget of the Turkish Republic following the War of Independence. ${ }^{78}$ Still however, this process was not selfevident, nor straightforward. For one, it took years of lengthy, and once again utterly confused, parliamentary debates to resolve the categorical messiness inherent in the new definitions of abandoned property, which treated all absentee property owners-whether fugitive, disappeared, or even killed — as one and the same. ${ }^{79}$ Such concepts as legal heirs or proxies vis-à-vis abandoned property also took lengthy efforts to resolve, ${ }^{80}$ as the subsequent governments strove to attain legitimate means for "the people's" ownership of "things."

The novelty of the War of Independence was that it fomented, among other things a radical redefinition of property ownership that was strictly along national lines. By the end of the war, the question of property, particularly of public property, was no longer solely about the legitimate ownership of "things" by a body referred to indistinctly as "the people," as was the case during the appropriation of Y1ldiz Palace or even during the early phases of Armenian genocide. ${ }^{81}$ Instead, it has become a question of, as Ellinor Morack has eloquently shown, "who the nation was, whether or not it could be represented, and if yes, by whom;" 82 a question that went on to inform the legislative processes in the aftermath of the war, not only on the continued appropriation of abandoned property but also the impending abolition of caliphate and the expropriation of dynastic property which it was intimately linked with. For one, the earlier discussions on the appropriation of Y1ldiz Palace depicted Abdülhamid II primarily as an unjust ruler who amassed his property through illegitimate means. The new debates on the abolition of the caliphate and the implied expropriation of dynastic property, on the other hand, 
were informed by and paralleled this increasingly more radicalized discourse on who the nation was ${ }^{83}$ and sought to define Abdülmecid II and other members of the dynastic family principally as undeserving citizens. ${ }^{84}$

After lengthy deliberations over the years, and not without ample reservation, ${ }^{85}$ the "Law on the abolition of Caliphate and exile of the dynasty members" passed on 3 March $1924{ }^{86}$ As the title indicates, it not only abrogated the office of the Caliph but also ordered all members of the dynasty to leave the country at once. The reasoning, with which the bill of law was introduced, was rather straightforward: the existence of the office and the imminent threat that it posed undermined the efforts of the Republican state in establishing itself as sovereign, and potentially had destructive effects on the future of the new political order. ${ }^{87}$ Signed and presented by the president of the Commission on Standing Orders (Nizamname-i Dahilî Encümeni) and 53 other deputies, the thirteen-item bill touched upon all presumed complications resulting from the abolition and expulsion. Six of these items were about the regulations and management of dynastic property alone. ${ }^{88}$

Shortly before the law was brought to the parliament, the problem of dynasty was raised during the budgetary discussions in a slightly different, yet more poignant way. When it was disclosed that the first Republican governmental budget contained a hefty sum set aside for the use of the dynastic family, Istanbul deputy Yusuf Akçura Bey led the way in offering heavy criticism. ${ }^{89}$ In no republican order existed a noble class that constituted a dynasty, Akçura noted. The bylaws of the ruling Republican People's Party (Cumhuriyet Halk Firkası) also made it clear by its second clause: its members, largely the Republican government, were obliged to do away with the privileges granted to "any 
family, class, congregation or individual. ${ }^{90}$ For Akçura and many others who concurred with him, the budget set aside for or allowances paid to the caliph or the other members of the Ottoman dynasty were essentially incompatible with the very definition of the republic itself. Denizli deputy Mazhar Müfit Bey took the discussion even further in the following session: the dynasty had no share in the national budget because only those who could make justified citizenship rights claims could have a share in it. The dynastic family, with all the "shine" Mazhar Müfit Bey specified, was neither. Nor were they on any sort of duty on behalf of "the people."

This intrinsic contradiction of dynastic presence in the republican order was dealt with, in no less contradictory manner, in the first clause of the Law on the abolition of Caliphate, enacted a week later. The law unambiguously stipulated that 1) each and every member of the Ottoman dynasty was now stripped indefinitely of their-largely inexistent—citizenship and rights to reside within the borders of the Turkish Republic, which they had to leave within ten days; 2) no member of the dynasty could own real property in the country and whatever property they owned had to be liquidated within a year and following a particular legal procedure; 3 ) all land titles that belonged to the dynasty, as well as all moveable property found at the palaces and other imperial buildings, such as furniture, jewelry, paintings and other types of art works were now transferred to "the people," understood as the nation (millete intikal etmiştir). ${ }^{92}$

Specified for most part as excessive pomp, and supported by the contemporary press as such, the lengthy discussion that followed the introduction of the bill at the parliament drew clear connections between the excessive splendor that was still existent in the palaces and both the excessive poverty and "backwardness" of "the people."93 
Highly supportive of the Republican government's recent resolution, and mirroring for most part the parliamentary debates, the newspapers and journals went as far as calling the Ottoman dynasty as the parasitic class (tufeyli sinuf) to highlight its incompatibility with the republican order. ${ }^{94}$ Six items of the proposed law, which were directly related to the issue of dynastic property, were accepted without any debate or discussion, let alone contestation. $^{95}$

Despite it being unambiguous and that it was accepted almost unanimously, the law brought about a whole new range of complications, which were reminiscent of the difficulties that the preceding governments had grappled with in the previous decade and a half. Stuck with a large number of buildings and things in its possession, the republican government faced the challenge of putting these items into reuse in safe and meaningful ways for public good or benefit. Not unlike Yıldız Palace, which was condemned as the "monument of despotism" during the constitutional era, each of these newly confiscated palaces and imperial buildings were now denounced as the root cause of "today's distresses and disasters. ${ }^{96}$ Yet, the dynastic buildings and things were deemed to embody not only the "burdensome past" of the Ottoman Empire but also its imagined grandeur. To give but one example, an official proposal opened to deliberation in May 1924 that suggested removing all Ottoman coat of arms, imperial seals and symbols from the government offices, schools, and hospitals, many of which were placed presumably during the reign of Abdulhamid II, was met with nearly as much objection as support at the parliament. ${ }^{97}$ Thus, the republican government had to tread the line between these realms of desired and undesired, that is "selective," pasts with utmost care. ${ }^{98}$ 
Aided by a rhetoric exemplified in a Resimli Ay article shortly after the abolition of the caliphate, the new government defined all dynastic buildings (and objects they contained) as "treasure troves of unequaled value," yet "made of blood of the nation/people." ${ }^{99}$ In the months that followed, the contemporary press continued to exploit this theme at great length, frequently inviting their readers "to take their minds off of the poverty and misery that surround[ed] them" by taking virtual tours of Topkap1 Palace, "where [the miseries of] the people had rarely ever reached before." ${ }^{100}$ Even the guidebook, written for the actual visitors of Topkapı Palace, which opened its doors to general public in October 1924, played on a similar juxtaposition. ${ }^{101}$ The booklet presented the palace to its prospective visitors similarly as a treasure trove which had been out of Turks[ish citizens]' reach for most of its existence (particularly during the Hamidian era, the introductory text specified) and served only a small group of privileged Ottoman and foreign visitors. ${ }^{102}$

Outside of this specific rhetorical function, dynastic property was put to a number of different uses by the Republican government, all tainted, in varying degrees, by a similar sort of ambivalence. Most obvious of these uses had to do with the palace buildings' and things' museum content and value. In European context, by the second half of the eighteenth century, vast collections of valuable and rare items and spectacular buildings that housed them were seen as the manifestation not solely of sovereign's power, but also increasingly of national might and pride, and by the same token, good governance. ${ }^{103}$ Not unlike post-revolutionary France, the Ottoman palace buildings and things in the early Republican era carried the potential of becoming "a sign of popular sovereignty and triumph" over a "treacherous and parasitic" order, inciting a "communal 
enjoyment of nationalized property ... contribut[ing] to ... the 'republican mold." ${ }^{104}$ As Wendy Shaw argued for the Ottoman case, museums, including the newly converted palaces, became expressions of a "national idea" and eventually assumed a new level of significance during and after the national struggle. ${ }^{105}$

What is less obvious perhaps and more easily taken for granted than its ideological dimension is the material aspect of this transformation. For, as the Kırşehir deputy Yahya Galib asserted, "nationalizing” imperial palaces and buildings was not enough to make them "national" (milli). Only when they were put into reuse in a meaningful institutional capacity, for the benefit of the public, they would become so. ${ }^{106}$ By that, Yahya Galib did not solely mean the conversion of palaces into national museums; he also meant that the dynastic property had to be transformed into schools, hospitals, and other public buildings and "things" of the new republic. ${ }^{107}$ When Yahya Galib stressed this point at the parliament, various commissions for inventorying and registering dynastic property were already at work towards that end. ${ }^{108}$ In July 1924, a commission was formed to classify things found in "Dolmabahçe, Y1ldı, Beylerbeyi" palaces, for the specific purpose furnishing the new building of the Grand National Assembly in Ankara. ${ }^{109}$ In an official note, the Ministry of Finance asked the Office of the Prime Minister to oversee the administrative and legal procedures for the transaction of sixty items chosen for this purpose, a list that comprised not only valuable art pieces such as a number of Aivazovsky paintings, but also small, trivial items such as an enameled cigarette box and a gilt tobacco stand, a lacquered coat hanger, vases and curtains, among other things. ${ }^{110}$ 
In the following year, reportedly another 335 items were sent to Ankara to be used in furnishing the Assembly Building, in addition to many others that were distributed to various ministry buildings as well as embassies and consulates abroad. ${ }^{111}$ More things were dispensed in the subsequent years, to furnish schools, orphanages, government institutions, as well as the newly established "Diplomats' Club" which aimed to host and entertain the foreign representatives resident in Ankara. ${ }^{12}$ Various presidential mansions, particularly the primary residence in Ankara, Çankaya Köşkü, itself confiscated from the wealthy Armenian Kasabian family during the Armenian genocide a decade earlier, were also furnished, for most part, with things taken from the imperial palaces. ${ }^{113}$

As dynastic things continued to flow towards Ankara, a specter of the Ottoman dynasty began to haunt the Republican administration. For one, all Ottoman coat of arms, imperial seals and symbols were ordered to be removed from the government offices, schools, and hospitals by a governmental decree in 1925 , ostensibly because they were incompatible with the "notion of the republic" (cumhuriyet mefhumu) ${ }^{114}$ That the Law on the Maintenance of Order (Takrir-i Sükûn Kanunu), which came into effect the same year to suppress all popular and political opposition, was extended to dynastic symbols and images in circulation via print media, indicates that there was more to the removal of these symbols than a simple conceptual incompatibility. ${ }^{115}$ The Republican government was aware that destroying, erasing, or tucking away the dynastic signs, symbols, and images were laden with new ambiguities and dangers. As one governmental decree made it clear, for instance, an all-encompassing erasure process would perpetuate a public 
debate, which carried an apparent risk of highlighting and bolstering the dynastic claims on buildings and things in question. ${ }^{116}$

Perhaps it was to counter this imminent claim that, in the ensuing years, the Republican government tightly knit its own power and might with the buildings and things they had taken over, especially if they were "shiny" enough. To give but one example, every year the Ministry of Foreign Affairs borrowed a set of gilt tableware from the Directorate of National Palaces (a new institution established to oversee the use and maintenance of dynastic property) by the direct orders of Mustafa Kemal, to be used in the banquets they were holding for foreign representatives, for the occasion of Republic Day that commemorated the proclamation of the republic. ${ }^{117}$ The palace buildings themselves were also put into use for important diplomatic conferences, and official visits from foreign royalty were given a royal treatment with the use of imperial buildings and things, both in Istanbul and Ankara. ${ }^{118}$ What is perplexing is that this took place on the personal level as well. Upon becoming the chair of Grand National Assembly, Kazım Paşa brought with him to Ankara the things given to his use at Dolmabahçe Palace, where he spent the previous summer; a list of 57 items that comprised, among other things, a confectionary plate, a whisk broom, and a soap dish. ${ }^{119}$ Unsurprisingly in this context, on his first return to Istanbul in 1927, after eight years of absence, Mustafa Kemal ceremoniously entered the Dolmabahçe Palace, ${ }^{120}$ held a banquet in its Grand Ceremonial Hall just as the Ottoman sultans did until a few years earlier, and continued to live there intermittently until his death a decade later.

Despite the increased usage and circulation of dynastic buildings and things by and for "the people," the republican administration still was still less than clear as to what 
it meant in actuality. Accordingly, the question of property as a means to understand "who the nation was" and who represented it, once again took central importance. The lengthy debates of the constitutional era had now largely given way to short, sharp interrogations, but a degree of ambiguity still loomed large in the parliamentary sessions on the transfer and ownership of dynastic property. Such was the case with the things given to the Grand National Assembly, when the Trabzon deputy Muhtar Bey brought the matter to the parliament as a formal question. ${ }^{121}$ In a concise yet boldly inquisitive manner, Muhtar Bey asked the Finance Minister Mustafa Abdülhalik Bey to reveal the legal and administrative procedure for the said transfer. Were these items, all of which were deemed valuable national property (emlak-l milliye), given to the Assembly within the limits of law and in exchange for their monetary value? "This chandelier [above us]," Muhtar Bey exemplified, "did the Ministry of Finance receive a payment for it or make budgetary arrangements for its compensation?" Mustafa Abdülhalik Bey tried to explain that a procedure for their legal appropriation had begun but has not been brought to a conclusion yet. When further pushed for more detailed explanations, he suddenly uttered: "I do not see any difference between these items being kept there at the palace or here [in this building] ... the [actual] goal is to maintain them; here or there, they are maintained in our name. This building is ours but so is the palace, it too is ours!"122

Not entirely clear yet perhaps, but in contrast to the constitutional government's insecure utterances on a vague notion of "the people" a decade and a half earlier, the Republican government now appeared surer and more unhindered about its jurisdictional limits. More than simply possessing the dynastic buildings and things, it now claimed the 
authority and power to command how they could and should be put into use, and

answered, along the way, who the nation was and what it took for it to own "things."

Author's note: The first, albeit a very different version of this article was presented at the "People and Things on the Move" workshop at Neubauer Collegium for Culture and Society, University of Chicago in May 2015. I thank the organizers Leora Auslander and Tara Zahra, and the workshop participants, whose insightful feedback had been instrumental in shaping the later course that this article took. At the University of Pennsylvania, I thank Peter Holquist and Mehmet Darakcioglu, who read and listened to the paper and offered invaluable suggestions. At SOAS, I am thankful to Nelida Fuccaro, Hugh Kennedy, Yorgos Dedes, and especially Derek Mancini Lander, who not only invited me to present the article at SOAS's Near and Middle East History Seminar but also read it closely and provided much needed direction for it. I am also indebted to Avner Wishnitzer, Yaşar Tolga Cora, Erdem Sönmez, and Yiğit Akın for their generosity in taking time to read and comment on different versions of the paper. I also thank the covenors of the Cambridge Middle East History Group Seminar, Helen Pfeifer, Andrew Arsan, and Arthur Asseraf, as well as the seminar participants Kate Fleet, Ebru Boyar, and Deniz Turker, for their invaluable input in bringing this article to conclusion. Last but not least, I am grateful to the anonymous readers at IJMES, most notably Reviewer 1 for their thorough categorizations, as well as the editors Akram Khater and Jeffrey Culang for a highly rewarding and pleasant review process.

${ }^{1}$ Başbakanlık Ottoman Archives (hereafter, BOA), DH.MUI 40-1/49, 1327.Z.5 (18 December 1909).

${ }^{2}$ Betül İpşirli Argit, "Manumitted Female Slaves of the Ottoman Imperial Harem (Sarayîs) in Eighteenth-Century Istanbul," (Ph.D. Dissertation, Boğaziçi University, 2009), 109. For a vivid depiction of the dethronement and removal process, see Ziya Şakir, Çıră̆an Sarayı 'nda 28 Yıl: Beşinci Murad (Istanbul: Kaknüs Yayınları, 2007), 109.

${ }^{3}$ BOA, DH.MUI 40-1/49.

${ }^{4}$ Leslie Peirce, The Imperial Harem: Women and Sovereignty in the Ottoman Empire (New York: Oxford University Press, 1993), 186-191; Rhoads Murphey, Exploring Ottoman Sovereignty: Tradition, Image and Practice in the Ottoman Imperial Household, 1400-1800 (London: Continuum, 2008), 7; Kaya Şahin, "Staging an Empire: An Ottoman Circumcision Ceremony as Cultural Performance," The American Historical Review, Volume 123, Issue 2, 1 April 2018, 478-479; Selim Deringil, The Well-Protected Domains: Ideology and the Legitimation of Power in the Ottoman Empire 1876-1909 (London: I.B. Tauris, 1998), 16-43.

${ }^{5}$ Tülay Artan, "Forms and Forums of Expression: Istanbul and beyond, 1600-1800," in The Ottoman World, Christine Woodhead (ed.) (Abingdon, Oxon: Routledge, 2012), 394-395; Marinos Sariyannis, "Ruler and State, State and Society in Ottoman Political Thought," Turkish Historical Review, Volume 4 (2013), 120-124; Murphey, Exploring Ottoman Sovereignty, 7-8.

${ }^{6}$ C. A. Bayly, Birth of the Modern World 1780-1914: Global Connections and Comparisons (Oxford: Blackwell, 2004), 112; For the Ottoman case, see Sibel Zandi-Sayek, "Ambiguities of Sovereignty: Property Rights and Spectacles of Statehood in Tanzimat Izmir," in Imperial 
Geographies in Byzantine and Ottoman Space, eds. Sahar Bazzaz et al. (Washington, DC: Center for Hellenic Studies, 2013), 150 and Huri Islamoglu, "Property as a Contested Domain: A Reevaluation of the Ottoman Land Code of 1858," in New Perspectives on Property and Land in the Middle East, ed. Roger Owen (Cambridge, MA: Harvard University Press, 2000). A product of liberal ideas recast in the late nineteenth century, the "project of res publica" had many precedents and parallels in the globe, a close example to that of the Ottoman experience came from Imperial and Soviet Russia. For a thorough analysis of the case of Imperial Russia, see Ekaterina Pravilova, A Public Empire: Property and the Quest for the Common Good in Imperial Russia (Princeton: Princeton University Press, 2014). For the Soviet case, see Anne O'Donnell, "A Noah's Ark: Material Life and the Foundations of Soviet Governance, 1916-1922," (Ph.D. Dissertation, Princeton University, 2014).

${ }^{7}$ Selim Deringil, "The Invention of Tradition as Public Image in the Late Ottoman Empire, 1808 to 1908," Comparative Studies in Society and History, Vol. 35, No. 1 (Jan., 1993).

${ }^{8}$ Şahin, "Staging an Empire," 464.

${ }^{9}$ Deringil, The Well-Protected Domains, 26.

${ }^{10}$ Across the paper, the term "the people" is used as the collective body of the people that was in the process of being redefined as the new sovereign. However, as with many other liberal fictions, "the people" is a highly elusive concept and what it signified varied from one context to another, an elusiveness that was widely present in the parliamentary debates, which I tried to capture and maintain throughout the article. The other, equally important, point to be made here has to do with "things" that are treated simply and uniformly as such throughout the article. This is not to disregard the fact that law treated different types and subtypes of property differently and that each type of "thing" had its own brand of agency. Yet, fascinatingly, the parliamentary debates lack that distinction entirely. While this lack is partially attributable to the general confusion with which the issue was debated at the parliament, it is more indicative of the legislative process' distinctiveness from the judiciary. As Edward Rubin has noted, in the modern administrative states, which the Ottoman constitutional order was in the process of becoming one, "legislatures allocate[d] resources, create[d] administrative agencies, issue[d] vague guidelines or general grants of jurisdiction to those agencies, and enact[ed] a wide range of other provisions," which bore only tangential similarities to the traditional concept of law. Edward L. Rubin, "Law and Legislation in the Administrative State," Columbia Law Review, Vol. 89, No. 3 (Apr., 1989), 369.

${ }^{11}$ Ellinor Morack, The Dowry of the State? The Politics of Abandoned Property and the Population Exchange in Turkey, 1921-1945 (Bamberg: University of Bamberg Press, 2017), 4.

${ }^{12}$ Nadir Özbek, "The Politics of Taxation and the "Armenian Question" during the Late Ottoman Empire, 1876-1908," Comparative Studies in Society and History, 54(4) (2012), 773; For a theoretical treatment of the governmental logic that sets these limits, see Michel Foucault, Security, Territory, Population: Lectures at the Collège de France, 1977-1978 (New York: Picador, 2007), 256-57; Michel Foucault, The Birth of Biopolitics: Lectures at the Collège de France, 1978-1979 (New York: Picador, 2008), 4.

${ }^{13}$ Morack, The Dowry of the State?; Mehmet Polatel, "Armenians and the Land Question in the Ottoman Empire 1870-1914” (Ph.D. Dissertation, Boğaziçi University, 2017); Bedross Der Matossian, "The Taboo within the Taboo: The Fate of 'Armenian Capital' at the End of the Ottoman Empire," European Journal of Turkish Studies [Online], Complete List, 2011, Online since 06 October 2011, connection on 19 December 2017. URL: http://journals.openedition.org/ejts/4411; Uğur Ümit Üngör and Mehmet Polatel, Confiscation and Destruction: The Young Turk Seizure of Armenian Property (London: Continuum 
International Publishing Group, 2011); Taner Akçam and Ümit Kurt, The Spirit of the Laws. The Plunder of Wealth in the Armenian Genocide (New York: Berghahn, 2015); Nevzat Onaran, Osmanlı'da Ermeni ve Rum Mallarının Türkleştirilmesi (1914 - 1919) and Cumhuriyet'te Ermeni ve Rum Mallarının Türkleştirilmesi (1920 - 1930) Emvâl-i Metrûkenin Tasfiyesi-I\&II (Istanbul: Evrensel, 2013).

${ }^{14}$ Üngör and Polatel, Confiscation and Destruction, 6-7; Morack, The Dowry of the State, 7.

${ }^{15}$ Özbek, "The Politics of Taxation," 773; Giorgio Agamben, Homo Sacer: Sovereign Power and Bare Life (Stanford: Stanford University Press, 1998). One prominent exception to this is Ellinor Morack's The Dowry of the State, which provides, throughout the book, thorough analyses of the contradictions and discrepancies between different governmental objectives and practices.

${ }^{16}$ Lerna Ekmekcioglu, "Republic of Paradox: The League of Nations Minority Protection Regime and the New Turkey's Step-Citizens," International Journal of Middle East Studies, vol. 46, issue 4 (November 2014), 660.

${ }^{17}$ Morack, The Dowry of the State, 78.

${ }^{18}$ For an illustrative anecdote on the degree of blurriness of this line, see Sariyannis, "Ruler and the State," 121-122. Literally meaning "house of wealth," bayt al-māl (beytü'l mal in Turkish) denotes royal treasury of the sultans and caliphs in Islamic jurisprudence and was regulated in accordance with Islamic (sharì'a) law, Noel J. Coulson et al., "Bayt al-Māl", in Encyclopaedia of Islam, Second Edition, Ed. Consulted online on 10 August 2018 http://dx.doi.org/10.1163/15733912_islam_COM_0109. For a comprehensive theoretical treatment of the problematic relationship between the person of the sovereign and the legal realm, see Ernst H. Kantorowicz's seminal study The King's Two Bodies: A Study in Medieval Political Theology (Princeton: Princeton University Press, 2016). For a cautionary note on complex private relations based on the shari' $a$ property regime and the lack of a "historical dichotomous relation with a notion of the "public,"” see Brinkley Messick, "Property and the Private in a Sharia System," Social Research: An International Quarterly, Volume 70, Number 3, Fall 2003, 712.

${ }^{19}$ Şükrü Hanioğlu, A Brief History of the Late Ottoman Empire (Princeton, NJ: Princeton University Press, 2008), 148.

${ }^{20}$ Bedross Der Matossian, Shattered Dreams of Revolution: From Liberty to Violence in the Late Ottoman Empire (Stanford, CA: Stanford University Press, 2014), 151.

${ }^{21}$ Nader Sohrabi, Revolution and Constitutionalism in the Ottoman Empire and Iran (Cambridge: Cambridge University Press, 2011), 255.

${ }^{22}$ Ibid., 224.

${ }^{23}$ The most comprehensive study on the topic has been carried by late Yavuz Selim Karakışla "Exile Days of Abdülhamid II in Salonica (1909-1912) and Confiscation of his Wealth" (M.A. Thesis, Boğaziçi University, 1990), also published as a book entitled Exile Days of Sultan Abdïlhamid II in Salonika (1909-1912) (Istanbul: Libra Kitap, 2015). The first part of this article builds on Karakışla's excellent study, shifting the focus to the categorical limits of the process.

${ }^{24}$ Meclisi Mebusan Zabit Ceridesi (Parliamentary minutes, hereafter, MMZC), 18 Nisan 1325 (1 May 1909), 139-141.

${ }^{25}$ MMZC, 20 Kanunusani 1325 (2 February 1910), 92-115.

${ }^{26}$ MMZC, 18 Nisan 1325 (1 May 1909), 140; MMZC, 24 Haziran 1325 (7 July 1909), 215.

${ }^{27}$ MMZC, 18 Nisan 1325 (1 May 1909), 140. 
${ }^{28}$ Ibid.

${ }^{29}$ Ibid.

${ }^{30}$ MMZC, 19 Nisan 1325 (2 May 1909), 161.

${ }^{31}$ Ibid. 148-149.

${ }^{32}$ Ibid.

${ }^{33}$ MMZC, 21 Nisan 1325 (4 May 1909), 208; 2 Temmuz 1325 (15 July 1909), 365-384 and the appendix to the same session, 1-7. This is evident in the institutional correspondences as well. For example, see the note written by the office of the Grand Vizier to the Ministry of Finance, BOA, BEO 3543/265857, 1327.R.21 (12 May 1909). For other examples on endowment deeds or estates of deceased dynasty members, implied to be appropriated by him, see BEO 3582/268577, 1327.C.5 (24 June 1909), BEO 3581/268565, 1327.C.5 (24 June 1909); MMZC, 21 Nisan 1325, 208.

${ }^{34}$ Sohrabi, Revolution and Constitutionalism, 267-269.

${ }^{35}$ MMZC, 21 Nisan 1325 (4 May 1909), 207-208. Also see MMZC, 25 Nisan 1325 (8 May 1909), 272 and MMZC, 3 May1s 1325 (16 May 1909), 417-418.

${ }^{36}$ Başbakalık Ottoman Archives contains numerous documents on tracing, locating and appraising Abdülhamid's wealth deposited in domestic and foreign banks. For the first and most comprehensive of these, see BOA, BEO 3542/ 265617, 1327.R.15 (6 May 1909).

37 “Şehzade Burhaneddin Efendi,"Tanin, 4 Mayıs 1325 (17 May 1909), 3.

${ }^{38}$ BOA, BEO 3542/ 265617, 1327.R.15 (6 May 1909).

${ }^{39}$ MMZC, 21 Nisan 1325 (4 May 1909), 208.

${ }^{40}$ Ibid., 209.

${ }^{41}$ Files pertaining to the requests and communiqués in that effect are numerous at BOA. For a few of those, see BOA, BEO 3542/ 265617, 1327.R.15 (6 May 1909) and the files connected to it, such as BEO 3582/268634, 1327.C.6 (25 June 1909); BEO 3631/272316, 1327.Ş.23 (9

September 1909); BEO 3690/276716, 1328.M.6 (18 January 1910); BEO 3711/278324, 1328.S.20 (3 March 1910).

${ }^{42}$ For the Deutsche Bank account for instance, which resulted in full recovery of Abdülhamid II's deposited money, stocks and bonds in July 1909, see Karakışla, Exile Days of Sultan Abdülhamid II, 138-140.

${ }^{43}$ For the Reichsbank case, see "Davayı Kazandık," Tanin, 25 Teşrin-i Sani (8 December 1910), 4. For the Crédit Lyonnais case, see Karakışla, Exile Days of Sultan Abdülhamid II, 146.

${ }^{44}$ MMZC, 4 May1s 1325 (17 May 1909), 480.

${ }^{45}$ Ibid., 480.

${ }^{46}$ Ibid., 481.

${ }^{47}$ BOA, DH.MUI 65/55, 1328.Ra.5 (17 March 1910).

${ }^{48}$ Ibid., 6.

${ }^{49}$ Ibid.

${ }^{50}$ Ibid., 2. 
${ }^{51}$ Karakışla, Exile Days of Sultan Abdülhamid II, 140-144.

${ }^{52}$ MMZC, 28 Temmuz 1325 (10 August 1909), 307.

${ }^{53}$ See MMZC, 24 Haziran 1325 (7 July 1909), 213-221, for the commission's initial report. For more specific cases see MMZC, 12 Nisan 1326 (25 April 1910), 370; "Yı1ldı Mefruşat1," Tanin, 13 Haziran 1325 (26 June 1909), 3.

54 "Y1ldı Otomobilleri," Tanin, 10 Haziran 1325 (23 June 1909), 4.

${ }^{55}$ MMZC, 16 Haziran 1325 (29 June 1909), 78.

56 “Y1ld1z Komisyon-u Mahsusundan,” Tanin, 8 Haziran 1325 (21 June 1909), 4.

57 “Y1ldız Hasılat1," Tanin, 9 Haziran 1325 (22 June 1909), 3.

58 "Y1ld1z Komisyonu," Tanin, 20 Haziran 1325 (3 July 1909), 4.

${ }^{59}$ MMZC, 8 Temmuz 1325 (21 July 1909), 473.

${ }^{60}$ BOA, DH.MUI 42/56, 1328.M.19 (31 January 1910).

${ }^{61}$ BOA, BEO 3673/275402, 1327.Za.22 (9 December 1909).

${ }^{62}$ BOA, BEO 3581/268552, 1327.C.4 (23 June 1909).

${ }^{63}$ For an excellent example of such criticism, see MMZC, 24 Haziran 1325 (7 July 1909), 215221.

${ }^{64}$ Yiğit Akın, When the War Came Home: The Ottomans' Great War and the Devastation of an Empire (Stanford: Stanford University Press, 2018), 3-4, 22.

${ }^{65}$ For late eighteenth and early nineteenth century applications, see Ali Yaycioglu, Partners of the Empire: The Crisis of the Ottoman Order in the Age of Revolutions (Stanford, CA: Stanford University Press, 2016), 107-111. For a more detailed study of the practice of müsadere, see Yasin Arslantaş, "Confiscation by the Ruler: A Study of the Ottoman Practice of Müsadere, 1700s-1839," (Ph.D. Dissertation, The London School of Economics and Political Science, 2017).

${ }^{66}$ Christine Philliou, Biography of an Empire: Governing Ottomans in an Age of Revolution (Berkeley: University of California Press, 2011), 30-31; 46-47. Both Mehmet Mert Sunar and Ellinor Morack note, however, in the aftermath of the Greek rebellion in 1821, property confiscations were extended to ordinary Greek subjects. Sunar, "Cauldron of Dissent: A Study of the Janissary Corps, 1807-1826," (Ph.D. Dissertation, Binghamton University State University of New York, 2006), 183-184; Morack, The Dowry of the State, 49-51.

${ }^{67}$ Sunar, "Cauldron of Dissent," 28, 216-227.

${ }^{68}$ Iris Agmon, Family and Court: Legal Culture and Modernity in Late Ottoman Palestine (Syracuse: Syracuse University Press, 2006), 148-150. For the differences from earlier practices of charity and poor relief, see Mine Ener, Managing Egypt's Poor and the Politics of Benevolence, 1800-1952 (Princeton: Princeton University Press, 2003).

${ }^{69}$ Nazan Maksudyan, Orphans and Destitute Children in the Late Ottoman Empire (Syracuse: Syracuse University Press, 2014), 108.

${ }^{70}$ Morack, The Dowry of the State, 119; Vladimir Hamed-Troyansky, "Circassian Refugees and the Making of Amman, 1878-1914," International Journal of Middle East Studies, Volume 49, Issue 4 (2017). 
${ }^{71}$ Samy Ayoub, "The Mecelle, Sharia, and the Ottoman State: Fashioning and Refashioning of Islamic Law in the Nineteenth and Twentieth Centuries," Journal of the Ottoman and Turkish Studies Association, Vol. 2, No. 1, Law and Legality in the Ottoman Empire and Republic of Turkey (Spring 2015), 136.

${ }^{72}$ Akın, When the War Came Home, 113-118. In addition to the Law on War Taxes that was reintroduced during the World War I, a law on the "Acquisition of Military Transport Vehicles," together with numerous other supplementary ones, remained in effect throughout the war. For an example of a supplementary law, see "Seferberlikte vaz-1 yed edilecek emakin ve mebani hakkında kanun,” Düstur, Tertib-i Sani, 8. Cilt, 1322 (14 October 1916).

${ }^{73}$ Coulson et al., "Bayt al-Māl", in Encyclopaedia of Islam.

${ }^{74}$ Morack, The Dowry of the State, 106.

${ }^{75}$ Ibid., 143-144.

${ }^{76}$ Üngör and Polatel, Confiscation and Destruction, 46; for the content of the law, see Düstur, Tertib-i Sani, 7. Cilt (Dersaadet: Matbaa-i Amire, 1336), 737-740 (27 September 1915).

77 “Ahir mahellere nakledilen eşhasın emval ve düyun ve matlubat-1 metrukesi hakkında kanun-1 muvakkat," Düstur, Tertib-i Sani, 7. Cilt , 737-738.

78 Üngör and Polatel, Confiscation and Destruction, 55-57; The temporary law was given a permanent status in November 1915 with procedural information and 14 additional items, some of which were amended in the following years. Düstur, Tertib-i Sani, 7. Cilt , 775-788 (10 November 1915); Düstur, Tertib-i Sani, 8. Cilt, 1322 (14 October 1916); Düstur, Tertib-i Sani, 9. Cilt, 759-760 (25 October 1917); Düstur, Tertib-i Sani, 10. Cilt, 22 (8 December 1917); Düstur, Tertib-i Sani, 11. Cilt, 553-560 (8 January 1920).

${ }^{79}$ Morack, The Dowry of the State, 148.

${ }^{80}$ Türkiye Büyük Millet Meclisi Zabit Ceridesi (Parliamentary minutes of the Grand National Assembly of Turkey, hereafter TBMMZC), 14.03.1337 (1921), 123, quoted in Morack, The Dowry of the State, 151.

${ }^{81}$ Morack, The Dowry of the State, 177.

${ }^{82}$ Ibid., 122.

${ }^{83}$ Ibid., 177. For a parliamentary debate in which the Greek and Armenian citizens were recast as rebels against the legitimate ruler (hurucu alelimam, khuruj 'ala al-imam), see TBMMZC, 16.04.1338 (1922), also quoted in Morack, The Dowry of the State, 165.

${ }^{84}$ TBMMCZ, 27.2.1340 (1924), 429-430.

${ }^{85}$ A highly controversial issue, the abolition of caliphate had been subject to lengthy deliberations almost from the beginning of the War of Independence. For an example of one such early debate, see Türkiye Büyük Millet Meclisi Gizli Celse Zabitları (Closed session minutes of the Grand National Assembly of Turkey, hereafter TBMMGCZ), 25.09.1336 (1920). Handling it rather cautiously and for most part secretly, the nascent Republican government delayed taking any action on the matter until the war and the peace negotiations came to a conclusion in late 1923. The general debates on the office of the Caliphate and its relationship to national sovereignty as well as the law were multifaceted and had produced a vast number of contemporary accounts. For an essay collection on the subject by contemporary thinkers, see Hilâfet ve Millî Hakimiyet (Ankara : Matbuat ve İstihbarat Müdüriyeti [Matbuat ve İstihbarat Matbaas1], 1339/1923). For 
legal and religious context, see Adliye Vekili Seyyid Bey, Hilâfetin Mahiyet-i Şer'iyesi (Ankara : Türkiye Büyük Millet Meclisi Matbaas1 [not dated]).

86 "Hilâfetin ilgasına ve Hanedan-1 Osmaninin Türkiye Cumhuriyeti Memaliki hâricine çıarılmasına dair teklif-i Kanuni,” TBMMCZ, 3.3.1340 (1924), 27-69.

${ }^{87}$ Ibid., 27.

${ }^{88}$ Ibid., 27.

${ }^{89}$ TBMMCZ, 25.2.1340 (1924), 345.

${ }^{90}$ Ibid., 345-346; Cumhuriyet Halk Firkası Nizamnamesi (Ankara, 1339/1923).

91 TBMMCZ, 27.2.1340 (1924), 429-430.

92 TBMMCZ, 3.3.1340 (1924), 28-29.

${ }^{93}$ Ibid., 29-31; Resimli Ay Mecmuası, no:2, vol:1, Mart 1340 (March 1924), 23.

${ }^{94}$ Ibid., 24.

${ }^{95}$ TBMMCZ, 3.3.1340 (1924), 68-69.

${ }^{96}$ Resimli Ay Mecmuasl, no:2, vol:1, Mart 1340 (March 1924), 20.

${ }^{97}$ TBMMZC, 5.1.1340 (1924), 665-666; Deringil, The Well-Protected Domains, 29.

98 Tony Bennett, The Birth of the Museum: History, Theory, Politics (London: Routledge, 1995), $128-162$.

${ }^{99}$ Resimli Ay Mecmuasl, no:3, vol:1, Nisan 1340 (April 1924), 20.

${ }^{100}$ Resimli Ay Mecmuast, no:6, vol:1, Temmuz 1340 (July 1924), 33, 36.

${ }^{101}$ İstanbul Asar-ı Atika Müzeleri, Topkapı Sarayl, Muhtasar Rehber (İstanbul: Matbaa-i Amire, 1341/1925).

${ }^{102}$ Ibid., 5-6. For a comprehensive overview of Topkap1 Palace's transformation in the long nineteenth century, see Nilay Özlü, "From Imperial Palace to Museum: The Topkapı Palace During the Long Nineteenth Century," (Ph.D. Dissertation, Boğaziçi University, 2018).

${ }^{103}$ Andrew McClellan, Inventing the Louvre: Art, Politics, and the Origins of the Modern Museum in Eighteenth-century Paris (Berkeley: University of California Press, 1994), 7.

${ }^{104}$ Ibid; This very point is also stressed by Sinop deputy Riza Nur, as he proposed the conversion of the palaces to museums, shortly after their full confiscation, TBMMZC, 9.3.1340 (1924), 202.

${ }^{105}$ Wendy M. K. Shaw, Possessors and Possessed: Museums, Archaeology, and the Visualization of History in the Late Ottoman Empire (Berkeley, CA: University of California Press, 2003), 188.

106 TBMMZC, 24.3.1340 (1924), 1030.

${ }^{107}$ Ibid.

${ }^{108}$ See the Finance Minister Mustafa Abdülhalik Bey's note in ibid.

${ }^{109}$ Başbakanlık Republican Archives (hereafter, BCA), 30181 1.10.35.7 / 132-34.

${ }^{110}$ For a detailed list of the items see BCA, 30181 1.10.35.7, 132-34 attachment, pages 166167. 
111 TBMMCZ, 5.1 .1341 (1925), 12; BCA, 30181 1.15.58.19, 132-34 attachment, pages 171173; BCA, 30181 1.1.14.39, 132-34 attachment, pages 135-139; BCA, 30181 1.16.77.3, 13234 attachment, pages 125-134.

${ }^{112}$ Records pertaining to such transfers are numerous at the Başbakanlık Republican Archives. For some illustrative cases, which are also attached to the large file of inventory lists, see BCA, 30181 1.19.35.7, 132-34; BCA, 30181 1.22.78.20, 132-34; BCA, 30181 1.20.59.12, 132-34; BCA, 30181 1.20.45.18, 132-34; BCA, 30181 1.22.78.16, 132-34; BCA, 3018 1.20.47.18, 132-34; BCA, 30181 1.21.64.10, 132-34.

${ }^{113}$ Zeynep Kezer, "Of Forgotten People and Forgotten Places: Nation-Building and the Dismantling of Ankara's non-Muslim Landscapes," in On Location: Heritage Cities and Sites, D. Fairchild Ruggles, ed. (New York: Springer, 2012), 174. BCA, 30181 2.28.37.16, 3-22. See attachment 3-22, pages 3-4, 7-10, 15-22 for the detailed list, which again contained such small, trivial items as doormats, mosquito nets, pitchers in addition to numerous bigger, valuable items, especially paintings.

${ }^{114}$ BCA, 30181 1.14.37.17.

${ }^{115} \mathrm{BCA}, 30181$ 1.14.43.7. For a related governmental decree that ordered the removal of all portraits of the Ottoman sultans from palace/museum displays, see BCA, 3018 1 1.15.53.2.

${ }^{116}$ BCA, 30181 1.15.59.12.

${ }^{117}$ BCA, 30181 2.14.68.15, 132-95; BCA, 3018 12.31.66.17, 132-117.

${ }^{118}$ BCA, 30181 2.23.67.10, 403-4; BCA, 30181 1.28.30.2, 239-39; BCA, 3018 1 1.28.26.10.

${ }^{119}$ BCA, 30181 1.26.63.15, 132-34.

120 “İstanbulluların Büyük Misafiri,” Servet-i Fünun, no. 1612-138, vol. 35, 7 Temmuz (July) 1927.

121 TBMMZC, 5.1.1341 (1925), 11.

122 TBMMZC, 5.1.1341 (1925), 12. 